\title{
The Dynamic of Cheating: Descriptive Study of Intention to Cheat
}

\author{
Ilham Phalosa Reswara \\ Faculty of Psychology, Universitas Padjajaran \\ Submitted 20 January $2020 \quad$ Accepted 19 May $2020 \quad$ Published 23 May 2020
}

\begin{abstract}
Cheating is strongly related to other unethical behaviors. It happens everywhere, including in universities. College students, ideally, should be prevented from cheating to minimize the potential of conducting unethical behaviors in the future. To design effective intervention, examining the cause of cheating is absolutely necessary. Cheating, like any other behavior, can be predicted by knowing its intention and the components of intention using the Theory of Planned Behavior. The present study explained the intention to cheat while studying in university along with its determinants and beliefs. The present study obtained data using online questionnaire based on the Theory of Planned Behavior to 233 participants. Regression analysis was performed to describe the significance level of each determinant and belief. The result showed that the determinant which had significant influence toward intention to cheat was attitude toward behavior $(\mathrm{p}=0.00 ; \beta=0.769 ; \mathrm{t}=$ 15.620). The most significant belief in that determinant was "cheating during learning in university can help one earning good grade without studying hard". Therefore, present study can be used as a basis to design interventions to reduce intention to cheat in university students.
\end{abstract}

Keywords: cheating; intention; students; theory of planned behavior; university

Cheating on academic work involves a diverse array of psychological phenomena, including learning, development, and motivation (Anderman \& Murdock, 2007). Therefore, cheating is conducted voluntarily and intentionally. In fact, to control and minimize such behavior, there are rules that have been created by the government, such as penalty for plagiarism as one of the cheating forms. Cheating is also related to other negative behaviors. It was found related to unethical behavior in the workplace (Davis \& Ludvigson, 1995; Lawson, 2004; Nonis \& Swift, 2001; Sims,

Address for correspondence:

ilham13011@mail.unpad.ac.id
1993; Thompson, 2000). Unethical behavior conducted in the workplace was mostly caused by one's attitude toward their surroundings that is already built by the previous behaviors (Sims, 1993). This correlation happens because of the belief that underlies the behavior (Lawson, 2004). When cheating is already perceived as an acceptable behavior, other unethical behaviors tend to be perceived in similar manner as well.

Ironically, cheating occurs frequently in universities. Approximately, this behavior was conducted by large percentage of university students (Klien, Levenburg, McKendall \& Mothersell, 2007; Mccabe, Butterfield \& Trevino, 2006; Rokovski \& Levy, 2007). This phenomenon 
also occurs in Indonesia. Cheating, whether during an examination or assignment, is conducted by nearly all accounting students (Rizaludin, 2014) and economy students (Friyatmi, 2011). Various ways are done for cheating, from exchanging answer, asking peers, using notes, to using cell phones (Friyatmi, 2011). Therefore, we need to examine this behavior thoroughly in order to be able prevent it.

Unfortunately, behavior is influenced by extensive number of factors. There can be demographic variables, personality characteristics, and situational factors. By the context of cheating, there are probabilities that cheating predictors for men are different from women, predictors for introvert are different from extrovert, predictors of cheating in national examination are different from a daily quiz, and so on. Of course, it would be difficult to examine those complex factors.

Then, it was found that intentions are the most approximate antecedents of behaviors (Fishbein, 1967). It means that by comprehending the intention and its determinant, we are likely able to explain and predict behavior. Of course there will be another behavior that precedes behavior, that is actual behavior control (ABC) (Fishbein \& Ajzen, 2010). ABC consists of more complex behavior and explains the variety of behaviors less than intention. Therefore, examining intention to perform behavior was needed to understand behaviors, what preceded it, and how to modify it.

The Theory of Planned Behavior (TPB) has been recognized as having a great theoretical power, especially in describing the process of forming an intention to do certain action (Ajzen, 2015). TPB is preceded by Theory of Reasoned Action (TRA) (Ajzen, 1985, 1991). TRA emphasizes on the causal antecedents of intentions to perform behaviors over which people have sufficient control (Ajzen, 2005). So, there is already a determinant that explains the inner factor (attitude toward behavior) and the social factor (perceived norm). Perceived behavior control (PBC) was added to this construct as a determinant in forming an intention in TPB. PBC was added because it can explain the process of perceived obstacle and supportive factor to conduct a behavior (Ajzen, 1991). These three comprehensive components are the reason why TPB has a big theoretical power.

There have been numerous studies which used TPB for explaining behaviors (Ahmed, Ambak, Raqib \& Sukor, 2013; Anderson \& Lavallee, 2008; Avci \& Yayli, 2014; Barmpagianni, Traylos, Kalokairinou, Sachlas \& Zyga, 2014; Kiriakidis, 2008; Luna $\&$ Chou, 2013). Previous research about cheating behavior suggested using TPB over TRA because TPB includes Perceived Behavior Control which makes this construct more comprehensive in explaining behavior (Simkin \& Mcleod, 2010). Previous research could not answer whether self-efficacy or control toward that behavior played a role in cheating behavior or not (Miller, 2005; Simkin \& Mcleod, 2010).

There are also debates about the role of each dimension toward intention. Attitude toward behavior was found to be dimension that contributes significantly toward intention to cheat (Carpenter, Harding, Finelli, Montgomerry \& Passow, 2006). On the contrary, attitude does not 
make a significant contribution toward intention in plagiarism (Ananto \& Juniarti, 2016). Therefore, the present study was conducted to complete previous study (Simkin \& Mcleod, 2010) and to clarify the role of each dimension and belief to intention of cheating in university.

\section{Method}

\section{Variable identification}

There were 4 variables analyzed in this study. First was intention. Intention stood as a different variable than its components. This condition would affect the analysis and the conclusion of how intention was formed (Fishbein \& Ajzen, 2010), it would be explained further in instrument subsection. Intention stood as the most proximate antecedent toward behavior and it was formed by the other variables attitude toward behavior, perceived norm, and perceived behavior control.

Second is attitude toward behavior. Attitude is a latent disposition or tendency to respond with some degree of favorableness toward a psychological object (Fishbein \& Ajzen, 2010). In this research, psychological object meant "cheating during learning in this university". Attitude is based on belief. Belief is subjective probability that an object has a certain attribute (Fishbein \& Ajzen, 2010), which means that it is related to cheating attribute, whether it could result in good grade or allow one to not study for test and so on.

Third is perceived norm. Perceived norm is defined as individual's perception that people who are important to they think they should (or should not) perform a particular behavior (Fishbein \& Ajzen,
2010). Perceived norm is based on normative belief, which is a belief that a particular reverent individual or group that thinks whether a certain action should be done or not.

Fourth is perceived behavior control. Perceived behavioral control is defined as the extent in which people believe that they are capable of performing a given behavior, that they have control over its performance (Fishbein \& Ajzen, 2010). Perceived behavior control is based on control belief, a belief about resources and opportunities individuals think they possess and obstacles or impediments to performing the behavior.

\section{Participants}

Present study sample was 223 participants: $98(43.9 \%)$ males and 125 (56.1\%) females. The sample was obtained through two stages cluster random sampling (Nazir, 1998). The population batch was limited considering their packed activity in college (still having daily classes and examinations). Cluster random sampling is a sampling technique from small group units, or cluster (Nazir, 1988). First stage was choosing primary sampling unit (PSU). Four faculties were chosen because in this university there are four academic complexes. So, each faculty represented its complex. Second stage, element unit inside PSU was chosen. The total number of all the four faculties was 195 .

\section{Instrument}

An inventory was created in this study. The inventory is called "Intention to Cheat Inventory". In present study, the behavior was defined as "cheating during learning in this university". The population was 
university student. The inventory consisted of 54 items, whereas 6 items measured intention, 12 items for attitude (direct measurement), 10 items for attitude (indirect measurement), 6 items for perceived norm (direct measurement), 8 items for perceived norm (indirect measurement), 4 items for perceived behavior control (direct measurement), and 8 items for perceived behavior control (indirect measurement).

The study measured intention through direct and indirect measurement to identify determinants and belief and its contribution toward intention (Fishbein \& Ajzen, 2010; Francis et al., 2004). Direct measurement or termed semantic differential, is an intention measurement done by asking respondent's attitude, perceived norm, and perceived control towards behavior regardless of its beliefs. In present study, direct measurement of attitude toward behavior was divided into instrumental quality (a mean to achieve something else) and experiential quality (experience) (Fishbein \& Ajzen, 2010). The item example of instrumental quality was "I gain certain advantages by cheating during my study in the university". The example of experiential quality was "I'm feeling satisfied when cheating during learning in the university".

Direct measurement of perceived norm consists of measurement for injunctive norm (environment expectation) and descriptive norm (social environment experience in the behavior) (Fishbein \& Ajzen, 2010). The item example of injunctive norm was "my closest people advise me to cheat in during learning in this university". The item example of descriptive norm was "I think, people who are significant to me cheatduring their study in the university".

Direct measurement of perceived behavior control consists of measurement for capability and controllability (Fishbein \& Ajzen, 2010). The item example of capability was "I'm sure I can cheat during my study in the university". The item example of controllability was "The decision to cheat during my study is under my control".

Meanwhile, indirect measurement is an intention measurement technique which is based on belief and its complement to form a related determinant (Fishbein \& Ajzen, 2010; Francis et al., 2004). There are several steps in creating indirect measurement.

First, researcher conducted an elicitation. Elicitation is a process to identify salient belief that underlies determinants (Fishbein \& Ajzen, 2010; Francis et al., 2004). The belief that is obtained through elicitation is used to construct the inventory. In attitude toward cheating, the most frequent beliefs were "can answer (examination) without learning", "can obtain a good grade", "feeling guilty", "unable to understand the subject", and "do not need to work hard". In perceived norm, the most frequent significant others were "lecturer", "parents", and "friends". In perceived behavior control, the most frequent beliefs were "the lecturer is strict", "running out of time", "the essayform is difficult to cheat on", and "did not prepare (study) well". 


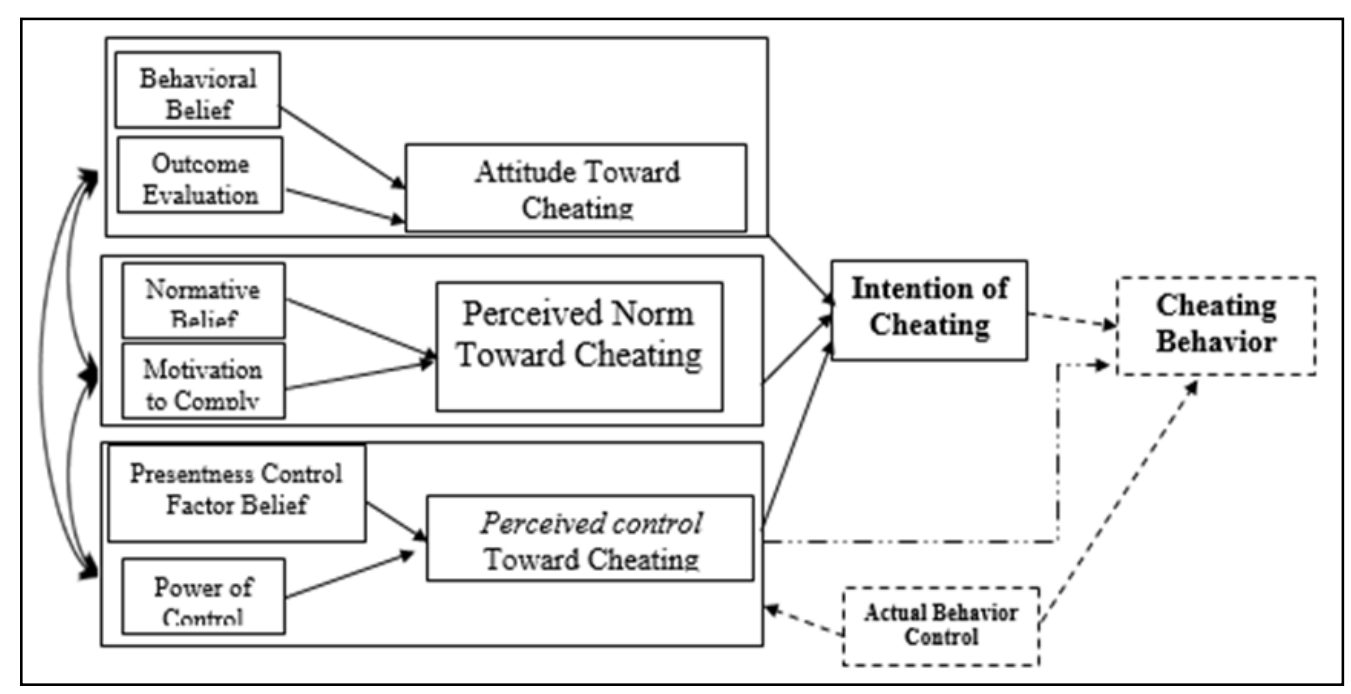

Figure 1. Theory of planned behavior framework.

Note: Variables examined in present study were presented by the straight lines. The dash lines were not examined.

After that, researcher created the complementary of each belief. In attitude toward behavior, the complement of behavior belief is outcome evaluation. For example, if the item of behavior belief was "If I cheat during my study in the university, I can obtain a good grade", the item of outcome evaluation was "obtaining a good grade is important for $m e^{\prime \prime}$. In perceived norm, the complement to normative belief is motivation to comply. For example, if the item in normative belief was "my close friends cheat during their studies", the item of motivation to comply was "doing what my close friends are doing is important to me". In perceived behavior control, the complement of control belief is perceived power. For example, if the item of control belief was "the time given to finish the assignment is not enough", the perceived power item was "the short timeline for finishing assignment makes me cheat during my study in the university".

The Cronbach's $\alpha$ was 0.748 which is categorized as reliable (Kaplan \& Saccuzzo, 2013). Researcher used content validity, to examine measurement's validity, by expert judgment. The experts were doctor in psychology, social psychologist, psychologist and psychometric expert. Researcher used Google Form to distribute the questionnaire.

\section{Method of analysis}

Researcher used regression analysis in present study. The analysis was based on TPB framework (Figure 1).

Multiple linear regression was needed to describe which determinant, between attitude, perceived norm, and perceived control, that had significant contribution toward intention to cheat (Fishbein \& Ajzen, 2010; Francis et al., 2004). In direct measurement, the sum of each determinant was placed as predictor and the sum of intention score was placed as the dependent variable. Statistical Package for Social Science (SPSS) 21.00 for Windows was used to perform multiple linear regression analysis. 
In indirect measurement, each belief was multiplied by its complement in that determinant. For example, in attitude, behavioral belief is multiplied by outcome evaluation. It is also applied to perceived norm belief and perceived control belief.

Method of successive interval was used to convert ordinal to interval scale (Junaidi, 2015). Microsoft Excel 2016 was used to perform method of successive interval. Then the determinant score from direct measurement was placed as a dependent variable and the indirect measurement score, the sum of belief multiplication, was placed as a predictor variable.

Besides the analysis above, researcher also analyzed the variables based on demographic characteristics. Researcher analyzed differences across gender, batch, and GPA.

\section{Results}

\section{Intention}

The data was normal (KolmogorovSmirnov, p-value $=0.871)($ Gravetter \& Wallnau, 2013). The regression, with significance level 0.05 , was significant [F (3, $219)=143.354, p=0.00]$. Only attitude toward cheating that had significant contribution toward intention to cheat ( $p$ value $=0.00 ; \beta=0.769 ; \mathrm{t}=15.620)$, meanwhile the other determinants (perceived norm and perceived control) did not $(\mathrm{p}$-value $=0.140 ; \beta=0.069 ; \mathrm{t}=1.482$ and $p$-value $=0.728 ; \beta=0.015 ; t=0.349)$. The equation of the result was Intention $=-2.65+$ 0.869 Attitude +0.105 Perceived Norm + 0.020 Perceived Behavioral Control. Results can be seen in table 1 .

In the same way, the present study also described the role of each attitude's belief. First, correlation test was done to examine whether there was any significant correlation between attitude toward cheating measured directly and attitude toward cheating measured indirectly. This procedure was needed because the belief from indirect measurement will be regressed toward the attitude from direct measurement. The correlation was 0.551 which is considered strong (Sarwono, 2006). The regression was significant $[F(5,217)=$ 29.206, $p=0.00$ ]. The results can be seen in table 2.

Only two beliefs that had significant contribution toward attitude. Belief 1 ( $\beta=$ 0.457, $\mathrm{p}=0.000$ ) was "belief that cheating during study period in university can help getting a good grade without studying rigorously". Belief $4(\beta=0.215, \mathrm{p}=0.046)$ was "belief that cheating during study period in university enables me to achieve a high grade". It meant that the student favored grade so much and wanted to achieve it through shortcut, which was cheating.

Table 1.

Regression of Attitude, Perceived Norm, and Perceived Control Toward Intention

\begin{tabular}{|c|c|c|c|}
\hline Model & $\mathrm{T}$ & Sig. & Beta \\
\hline Constant & -1.696 & .091 & - \\
\hline Attitude & 15.620 & .000 & .769 \\
\hline Perceived Norm & 1.482 & .140 & .069 \\
\hline Perceived Behavioral Control & .349 & .728 & .015 \\
\hline
\end{tabular}


Table 2.

Regression Analysis of Belief 1, Belief 2, Belief 3, Belief 4, and Belief 5 to Attitude Toward Cheating

\begin{tabular}{lccc}
\multicolumn{1}{c}{ Model } & $\mathbf{t}$ & Sig. & Beta \\
\hline Constant & 8.195 & .000 & - \\
Belief 1 & 6.618 & .000 & .457 \\
Belief 2 & .294 & .769 & .017 \\
Belief 3 & 1.160 & .247 & .081 \\
Belief 4 & 3.559 & .000 & .215 \\
Belief 5 & 1.116 & .266 & .060 \\
\hline
\end{tabular}

Demographic characteristic

There was no significant difference in intention to cheat between male and female $(p=0.089)$. Difference between male and female students was obtained to describe the condition across gender. There was no significant difference between batches $(\mathrm{p}=0.167)$. Difference between batches was analyzed to examine the dynamic between the semesters that respondents were into. Student with GPA 2.51 - 3.00 had higher intention to cheat compared to student with GPA 3.01 - 3.50 and GPA 3.51 - 4.00. Data across GPAs was obtained to describe student's ability in learning.

\section{Discussion}

Intention is the most powerful determinant in predicting whether one will perform any behavior or not (Fishbein \& Ajzen, 2010). Another factor that contributes to performance of any behavior is actual behavior control. This factor is the real condition in the real life that could not be predicted because of its complexity. Therefore, actual behavior, intention plays a significant role in predicting behaviors, including about cheating during studying in university.

Intention is determined by three variables, which are attitude, perceived norm, and perceived control. However, there is no need for three determinants to have a significant contribution toward intention (Fishbein \& Ajzen, 2010). According to the current study, only attitude toward cheating that had a significant contribution toward intention. This finding was also quite similar with previous studies proving there were determinants that did not have a significant role toward intention (Ahmed et al., 2013; Anderson \& Lavallee, 2008; Avci \& Yayli, 2014; Barmpagianni et al., 2014; Cahyo, 2016; Kiriakidis, 2008; Luna \& Chou, 2013).

This result was in line with several meta-analyses (Albarracín et al., 1998; Armitage \& Conner, 2001; Godin \& Kok, 1996; Hagger, Chatzisarantis \& Biddle, 2002) that attitude was found to be the most significant determinant that correlate with intention. The range of correlation attitude and intention was 0.45 to 0.60 , whereas perceived norm was 0.34 to 0.42 and perceived control was 0.35 to 0.46 (Fishbein \& Ajzen, 2010). Therefore, whether the student would have a high or low intention to cheat in university was significantly determined by their tendency to respond with some degree of favorableness to cheat. The perception or behavior of their significant people toward cheating and the perceived control toward performing 
cheating itself does not matter. It means that the determinant that should be scrutinized more to comprehend the antecedent of intention to cheat is attitude toward cheating during studying time in university.

Furthermore, describing the beliefs that underlies attitude toward cheating was important in order to comprehend more what preceded the attitude. The beliefs that significantly contributed to attitude toward cheating were all related to "obtaining a high grade". It proves that having a high grade is so important to university's students. It supported the notion that one of motivations for student to cheat was to compete with others (Simkin \& Mcleod, 2010). By cheating, students think that if they achieve high grades, they could compete with others for employments or other things that require them to have high GPA. That was why if cheating was needed to obtain a high grade, students will do it.

It is further supported by the result that showed students with middle to low GPA range significantly had a higher cheating intention compared to students with middle to high range. Having lower GPA often (not always) implies that the student has lower academic ability than those with higher GPA. Because the most significant belief that contributes to attitude toward cheating was obtaining high grades, student with lower GPA would have higher intention to cheat compared to the higher one.

The limitation of present study was the method of validating the instrument. The questionnaire could be validated using more advanced technique which is confirmatory factor analysis (Fishbein \& Ajzen, 2010)

\section{Conclusion}

From this study, it can be concluded, that attitude is the most significant determinant in forming an intention to cheat during learning in university. It meant that the student favorableness toward cheating is very important. If the student has favorable view toward cheating, then they are likely to have higher intention to cheat despite of the norm of their significant others and the ability to control self in performing the behavior.

Then, the most valuable thing for the students is having a high grade without having an effortful learning process. This was obtained from analysis of the most significant belief that contributed toward attitude.

Therefore, there should be schemas to reform education. If the students are just made to think about their grades, they would not appreciate and work for the process. This kind of attitude motivates them to cheat. An intervention should aim to change their attitude toward cheating, especially the belief that cheating could help them earning high grades without having an effortful learning process.

\section{Recommendation}

Further research about comparing the intention of students who cheat and who do not is recommended, along with its determinants and beliefs. This study also revealed that attitude has a significant role in cheating, meanwhile perceived norm and perceived behavior control have no significant role in intention to cheat. 
Therefore, if future research aims to develop an intervention, whether to prevent cheating or promote academic honesty, it is recommended that the intervention focus on how to change student's attitude about cheating, especially about beliefs "cheating during my study in university can help me getting a good grade without learning rigorously" and "cheating during my study in university enables me to get a high grade".

Acknowledgments: This research received no specific grant from any funding agency, commercial or not-for-profit sectors.

Competing Interest: The author reports no conflicts of interest in this work.

\section{References}

Ahmed, M. B., Ambak, K., Raqib, A., \& Sukor, N. S. (2013). Helmet usage among adolescents in rural road from the extended theory of planned behaviour. Journal of Applied Sciences, 13(1), 161-166. doi: 10.3923/jas.2013.161.166

Ajzen, I. (1985). From intentions to actions: A theory of planned behavior. In J. Kuhl \& J. Beckman (Eds.), Actioncontrol: From cognition to behavior (pp. 11-39). New York: Springer.

Ajzen, I. (1991). The theory of planned behavior. Organizational Behavior and Human Decision Processes, 50(2), 179211. doi: 10.1016/0749-5978(91)90020-T Ajzen, I. (2005). Attitudes, personality, and behavior (2nd ed.). United Kingdom:
McGraw-Hill Education.

Ajzen, I. (2015). The theory of planned behaviour is alive and well, and not ready to retire: a commentary on Sniehotta, Presseau, and AraújoSoares. Health Psychology Review, 9(2), 131-137.

doi:

\section{$\underline{10.1080 / 17437199.2014 .883474}$}

Albarracín, D., Fishbein, M., \& Middlestadt, S. (1998). Generalizing behavioral findings across times, samples, and measures: A study of condom use. Journal of Applied Social Psychology, 28(8), 657-674. doi: 10.1111/j.15591816.1998.tb01725.x

Ananto, N. D. \& Januarti, I. (2016). Analisis faktor internal dan eksternal yang mempengaruhi persepsi mahasiswa akuntansi terhadap tindakan plagiarisme dengan tekanan sebagai variabel moderating. Diponegoro Journal of Accounting, 5(3),1-15.

Anderman, E. M., \& Murdock, T. B. (2007). Psychology of academic cheating. Cambridge, MA: Academic Press.

Anderson, A. G., \& Lavallee, D. (2008). Applying the theories of reasoned action and planned behavior to athlete training adherence behavior. Applied Psychology, 57(2), 304-312. doi: 10.1111/j.1464-0597.2007.00310.x

Armitage, C. J., \& Conner, M. (2001). Efficacy of the theory of planned behavior: A meta-analytic review. British Journal of Social Psychology, 40(4), 471-499. doi: $\underline{10.1348 / 014466601164939}$

Avci, C., \& Yayli, A. (2014). Examining safety behaviour with the safety climate and the theory of planned behaviour. Retrieved from

https://www.researchgate.net/publicati 
on/269279025 EXAMINING SAFETY

BEHAVIOUR WITH THE SAFETY C

LIMATE AND THE THEORY OF P

LANNED BEHAVIOUR/link/5486164e

0cf268d28f044c1c/download

Barmpagianni, E., Travlos, A., Kalokairinou,

A., Sachlas, A., \& Zyga, S. (2014).

Predictors of smoking and alcohol use

behaviour in undergraduate students: application of the theory of planned behaviour. International Journal of Caring Sciences, 7(2), 477-487.

Cahyo, I. D. (2016). Gambaran intensi menikah dengan lawan jenis pada gay dewasa awal di Bandung. Sumedang: Universitas Padjadjaran.

Carpenter, D. D., Harding, T. S., Finelli, C. J., Montgomerry, S. M., \& Passow, H. J. (2006). Engineering students' perceptions of and attitudes towards cheating. Journal of Engineering Education, 95(3), 181-194.

Davis, S., \& Ludvigson, H. (1995). Additional data on academic dishonesty and proposal for remediation. Teaching of Psychology, 22(2), 119-121. doi: 10.1207/s15328023top2202 6

Fishbein, M. (1967). Attitude and the prediction of behavior. In M. Fishbein (Ed.), Readings in attitude theory and measurement (pp. 477-492). Wiley.

Fishbein, M., \& Ajzen, I. (2010). Predicting and changing behavior the reasoned action approach. Cambridge, MA: Psychology Press.

Francis, J. J., Eccles, M. P., Johnson, M., Walker, A., Grimshaw, J., Foy, R., Kaner, E. F. S., Smith, L., \& Bonetti, D. (2004). Constructing questionnaires based on the theory of planned behaviour: $A$ manual for health services researchers. Centre for Health Services Research, University of New Castle.

Friyatmi. (2011). Faktor-faktor penentu perilaku mencontek di kalangan mahasiswa. Tingkap, 7(2), 173-188.

Godin, G., \& Kok, G. (1996). The theory of planned behavior: A review of its applications to health-related behaviors. American Journal of Health Promotion, 11(2), 87-98. doi: $\underline{10.4278 / 0890-1171-11.2 .87}$

Gravetter, F. J., \& Wallnau, L. B. (2013). Statistics for the behavioral sciences (9th ed.). Wadsworth.

Hagger, M. S., Chatzisarantis, N. L. D., \& Biddle, S. J. H. (2002). A meta-analytic review of the theories of reasoned action and planned behavior in physical activity: Predictive validity and the contribution of additional variables. Journal of Sport and Exercise Psychology, 24(1), 3-32. doi: 10.1123/jsep.24.1.3

Junaidi. (2015). Transformasi data ordinal ke interval dengan Microsoft Office Excel. Retrieved from https://doi.org/10.13140/RG.2.1.3132.17 64

Kaplan, R. M., \& Saccuzzo, D. P. (2013). Psychological testing: Principles, applications, and issues (8th ed.). Boston, MA: Cengage Learning.

Kiriakidis, S. P. (2008). Application of the theory of planned behavior to recidivism: The role of personal norm in predicting behavioral intentions of re-offending. Journal of Applied Social Psychology, 38(9), 2210-2221. doi: 10.1111/j.1559-1816.2008.00388.x

Klien, H. A., Levenburg, N. M., McKendall, 
M., \& Mothersell, W. (2007). Cheating during the college years: How do business students compare? Journal of Business Ethics, 72, 197-206. doi: 10.1007/s10551-006-9165-7

Lawson, R. A. (2004). Is classroom cheating related to business students' propensity to cheat in the "real world"? Journal of Business Ethics, 49, 189-199. doi: 10.1023/B:BUSI.0000015784.34148.cb

Luna, A., \& Chou, S. Y. (2013). Drivers for workplace gossip: An application of the theory of planned behavior. Journal of Organizational Culture, Communications and Conflict, 17(1), 115130.

Mccabe, D. L., Butterfield, K. D., \& Trevino, L. K. (2006). Academic dishonesty in graduate business programs: Prevalence, causes, and proposed action. Academy of Management Learning and Education, 5(3), 294-305. doi: 10.5465/amle.2006.22697018

Miller, K. (2005). Communication theories: Perspectives, processes and contexts. McGraw-Hill.

Nazir, M. (1998). Metode penelitian. Jakarta: Ghalia Indonesia.

Nonis, S., \& Swift, C. (2001). Personal value profiles and ethical business decisions. Journal of Education for Business, 76(5),
251-256.

doi: $\underline{10.1080 / 08832320109599644}$

Rizaludin, A. (2014). Pengaruh iklim motivasional kelas terhadap perilaku menyontek mahasiswa Program Studi Akuntansi dan Program Studi Pendidikan Akuntansi di Universitas Pendidikan Indonesia (Unpublished undergraduate thesis). Bandung: Universitas Pendidikan Indonesia.

Rokovski, C., \& Levy, E. (2007). Academic dishonesty: Perceptions of business students. College Student Journal, 41(2), 466-481.

Sarwono, J. (2006). Metode penelitian kuantitatif dan kualitatif. Yogyakarta: Graha Ilmu.

Simkin, M. G., \& Mcleod, A. (2010). Why do college students cheat? Journal of Business Ethics, 94, 441-453. doi: 10.1007/s10551-009-0275-x

Sims, R. (1993). The relationship between academic dishonesty and unethical business practices. Journal of Education for Business, 68(4), 207-211. doi: $\underline{10.1080 / 08832323.1993 .10117614}$

Thompson, N. (2000, June). Survey finds 1 in 3 workers sees abuses. Baltimore Sun. Retrieved from https://www.baltimoresun.com/news/b s-xpm-2000-06-14-0006140183story.html 